\title{
Service Quality dan Implikasinya Terhadap Kepuasan Pelanggan
}

\author{
Resti Siti Nur Cahyati Hidayat ${ }^{1 *}$ dan Maya Setiawardani ${ }^{2}$ \\ ${ }^{1}$ Jurusan Administrasi Niaga, Politeknik Negeri Bandung, Indonesia \\ ${ }^{2}$ Jurusan Administrasi Niaga, Politeknik Negeri Bandung, Indonesia
}

\begin{abstract}
:
The high level of society mobility needs to be supported by adequate infrastructures. Sufficient toll road infrastructure is able to increase the acceleration of a country's economic and social development through the creation of effectiveness and resulting efficiency. Optimal service delivery can gain customer satisfaction. One approach to measure service quality that many used as a reference is SERVQUAL (Service Quality). There are five dimension on SERVQUAL model, that is reliability, assurance, tangible, emphaty and responsiveness. The purpose of this study is to determine the level of customer satisfaction in order to improve the quality of service and to know the service attributes that are prioritized to be maintained and improved by PT Jasa Marga (Persero) Branch Purbaleunyi. Data processing methods in this study using the validity, reliability, classical assumption test, and descriptive statistical analysis. While the data analysis methods used are simple linear regression analysis, correlation, coefficient of determination and quadrant analysis. The results of this study indicate that service quality variables have positive and significant impact on customer satisfaction at Purbaleunyi toll road.
\end{abstract}

Keywords: customer satisfaction, service quality, toll road

\begin{abstract}
Abstrak:
Tingginya mobilitas masyarakat perlu didukung oleh infrastruktur yang memadai. Infrastruktur jalan tol yang memadai mampu meningkatkan percepatan pembangunan ekonomi dan sosial suatu negara melalui penciptaan efektivitas dan efisiensi yang dihasilkan. Penyampaian layanan yang optimal bisa mendapatkan kepuasan pelanggan. Salah satu pendekatan untuk mengukur kualitas layanan yang banyak digunakan adalah SERVQUAL (service quality). Ada lima dimensi model SERVQUAL, yaitu reliability, assurance, tangible, emphaty dan responsiveness. Tujuan penelitian ini adalah mengetahui tingkat kepuasan pelanggan dalam rangka meningkatkan kualitas pelayanan dan mengetahui atribut layanan yang diprioritaskan untuk dipelihara dan diperbaiki oleh PT Jasa Marga (Persero) Cabang Purbaleunyi. Metode pengolahan data menggunakan uji validitas, reliabilitas, uji asumsi klasik, dan analisis statistik deskriptif. Sedangkan metode analisis data yang digunakan adalah analisis regresi linier sederhana, korelasi, koefisien determinasi dan analisis kuadran. Hasil penelitian ini menunjukkan bahwa variabel kualitas pelayanan berpengaruh positif dan signifikan terhadap kepuasan pelanggan pada jalan tol Purbaleunyi.
\end{abstract}

Kata Kunci: kepuasan pelanggan, kualitas layanan, jalan tol

PENDAHULUAN

PT Jasa Marga (Persero) sebagai

*Email korespondensi:

Resti Siti Nur Cahyati Hidayat

restysitinurcahyati@gmail.com operator dan investor di bidang jalan tol telah ikut mendukung pertumbuhan ekonomi daerah pada kota-kota besar di Indonesia. Salah satunya yaitu dengan pengoperasian tol Purbaleunyi, yang 
menghubungkan antara PurwakartaBandung-Cileunyi. Dukungan tersebut dilakukan dengan menjadi penghubung dan memberikan manfaat ekonomi dalam efisiensi distribusi barang maupun jasa.

Dalam rangka mendukung pembangunan infrastruktur jalan tol yang memadai, kualitas pelayanan jasa merupakan salah satu faktor penting yang perlu diperhatikan oleh perusahaan. Berdasarkan penelitian WHDP (2014: 6) "measuring service quality can help management provide reliable data that can be used to monitor and maintain improved service quality." Selain itu, pelayanan yang berkualitas berperan penting dalam membentuk dan mempengaruhi kepuasan pelanggan. Hal ini dibuktikan dari penelitian Tjoanoto dan Kunto (2013) yang menyatakan bahwa service quality secara signifikan mempengaruhi kepuasan pelanggan. Selain itu, dari penelitian Phan dan Nham (2015:288) pun diketahui bahwa:

"Service quality plays a significant role in maintaining and developing sustainable competitive advantage of company or firm because service quality influence directly customer satisfaction."

Berdasarkan hal tersebut dapat disimpulkan bahwa tingkat kepuasan pelanggan dapat ditentukan oleh pendapat pelanggan atas kinerja produk atau jasa yang diberikan dalam memenuhi kebutuhan pelanggan. Pelanggan dapat merasakan kepuasan apabila harapannya dapat terpenuhi atau akan sangat puas jika harapan pelanggan tersebut dapat terlampaui.

Industri jalan tol di Indonesia mempunyai Standar Pelayanan Minimal (SPM) yang ditetapkan berdasarkan Peraturan Menteri Pekerjaan Umum. No. 16/PRT/M/2014 tentang Standar Pelayanan Minimal Jalan Tol. Pada dasarnya standar ini merupakan bentuk kontrol pemerintah untuk melindungi pengguna jalan tol.
Regulasi ini berisi hal-hal yang harus dicapai Badan Usaha Jalan Tol (BUJT) dalam rangka meningkatkan kualitas pelayanan kepada pengguna jalan tol. Namun sayangnya, pada praktiknya masih terdapat beberapa BUJT yang belum memenuhi evaluasi SPM ini dari beberapa aspek layanan tertentu.

Menurut Zuna et al. (2015a) karena industri jalan tol termasuk jenis jasa yang tidak memiliki pasar kompetitif, maka pada beberapa kasus, operator jalan tol kurang memberikan pelayanan yang memenuhi harapan pengguna jalan tol. Sehingga, timbul ketidakpuasan terhadap kualitas penyediaan layanan tol di Indonesia, dimana operator tidak menyediakan kualitas layanan jalan tol sesuai dengan harapan pengguna, dan pemerintah sebagai regulator kurang mampu merepresentasikan ekspektasi dan harapan pengguna dalam standar pelayanan yang ditetapkan kepada operator, sehingga layanan yang diterima tidak sesuai dengan layanan yang diharapkan oleh mereka.

Berdasarkan hal tersebut, fokus penelitian ini akan membahas mengenai service quality dari sisi pelanggan. Salah satu pendekatan kualitas pelayanan yang banyak dijadikan acuan untuk mengukur kinerja pelayanan hingga saat ini adalah model SERVQUAL (Service Quality) yang dikembangkan oleh Parasuraman, Zeithaml, dan Berry. Model ini sudah banyak digunakan untuk menganalisis kualitas pelayanan di berbagai industri, termasuk salah satunya industri jalan tol. Penelitian sebelumnya yakni oleh Zuna et al. (2015b) menggunakan dimensi pada metode SERVQUAL dan menjadikan Standar Pelayanan Minimal (SPM) sebagai indikator untuk menilai kinerja kualitas layanan jalan tol di pulau Jawa. Model tersebutlah yang akan digunakan dalam penelitian ini. Penelitian ini berfokus pada bagaimana service quality dari segi persepsi dan ekspektasi pelanggan, bagaimana 
kepuasan pelanggan secara keseluruhan, serta bagaimana pengaruh persepsi service quality terhadap kepuasan pelanggan di tol Purbaleunyi.

\section{KAJIAN LITERATUR}

Service Quality

Menurut Parasuraman, Zeithaml dan Berry (1988: 30):

"SERVQUAL is a concise multipleitem scale with good reliability and validity that retailer can use to better understand the service expectation and perceptions of consumers and, as a result, improve service."

Berdasarkan pengertian tersebut, menurut Hindarwati dan Jayasari (2014) metode SERVQUAL secara garis besar terbagi menjadi 2 bagian yaitu:

1. Bagian ekspektasi (expected service) memuat pertanyaan-pertanyaan untuk mengetahui dengan pasti ekspektasi atau harapan (kepentingan) umum dari pelanggan terhadap sebuah jasa.

2. Bagian persepsi (perceived service) memuat pertanyaan-pertanyaan untuk mengukur persepsi pelanggan (tentang kinerja) layanan jasa yang diberikan oleh suatu perusahaan dengan kategori tertentu.

Parasuraman et al. (1988) membagi dimensi metode SERVQUAL ke dalam lima dimensi, yakni:

1. Dimensi Reliability (Keandalan) Kemampuan pihak penyedia jasa dalam memberikan jasa atau pelayanan secara tepat dan akurat sehingga pelanggan dapat mempercayai dan mengandalkannya.

2. Dimensi Assurance (Jaminan) Pemahaman dan sikap kesopanan dari karyawan (contact personnel) dikaitkan dengan kemampuan mereka dalam memberikan keyakinan kepada pelanggan bahwa pihak penyedia jasa mampu memberikan pelayanan dengan sebaik-baiknya.

3. Dimensi Tangibles (Nyata)

Penampilan dan performansi dari fasilitas-fasilitas fisik, peralatan, dan material-material komunikasi yang digunakan dalam proses penyampaian layanan.

4. Dimensi Empathy (Empati)

Tingkat perhatian atau tingkat kepedulian individual yang dapat diberikan pihak penyedia jasa kepada pelanggannya.

5. Dimensi Responsiveness (Daya Tanggap) Kemauan atau keinginan pihak penyedia jasa untuk segera memberikan bantuan pelayanan yang dibutuhkan pelanggan dengan cepat.

\section{Kepuasan Pelanggan}

Menurut Tjiptono (2011: 199) kepuasan pelanggan diartikan sebagai berikut:

"kepuasan pelanggan sebagai perasaan senang atau kecewa seseorang terhadap suatu produk setelah ia membandingkan hasil/prestasi produk yang dipikirkan terhadap kinerja atau hasil produk yang diharapkan."

Sedangkan menurut Bitner dan Hubbert (1994) "satisfaction can be considered at two levels: the transaction or encounter level and overall satisfaction". Hal tersebut disetujui pula oleh Yi dan La dalam Osotimehin et al. (2015: 148) yang menyatakan "generally, there are two general conceptualisations of satisfaction, namely, transaction-specific satisfaction and cumulative satisfaction." Berdasarkan pendapat tersebut dapat disimpulkan bahwa pada dasarnya terdapat dua konsep mengenai kepuasan pelanggan, dimana kepuasan dan kepuasan secara keseluruhan (overall satisfaction) memiliki konstruk 
tersendiri. Kepuasan terhadap transaksi spesifik merupakan evaluasi pelanggan atas pengalamannya terhadap layanan tertentu. Sedangkan kepuasan keseluruhan atau kumulatif mengacu pada keseluruhan evaluasi pelanggan terhadap pengalamannya dalam menggunakan suatu jasa hingga saat ini.

Taylor dan Baker (1994) mengembangkan pengukuran untuk menilai kepuasan pelanggan secara keseluruhan (overall satisfaction) yang dinyatakan menggunakan empat pernyataan dan diukur dengan alternatif jawaban menggunakan skala Likert, mulai dari very dissatisfied hingga very satisfied. Model ini lah yang digunakan untuk mengukur kepuasan pelanggan tol Purbaleunyi secara keseluruhan (overall satisfaction).

\section{Important Performance Analysis (IPA)}

Menurut Algifari (2016) tujuan utama IPA adalah sebagai alat diagnosis untuk memudahkan mengidentifikasi atribut-atribut yang didasarkan pada kepentingan masing-masing, apakah produk atau jasa tersebut berkinerja buruk atau berkinerja berlebih. Important Performance Analysis ditampilkan dalam sebuah grafik (derajat kartesius) yang memiliki empat kuadran. Gambar 1 berikut menggambarkan bentuk diagram kartesius dari important performance analysis.

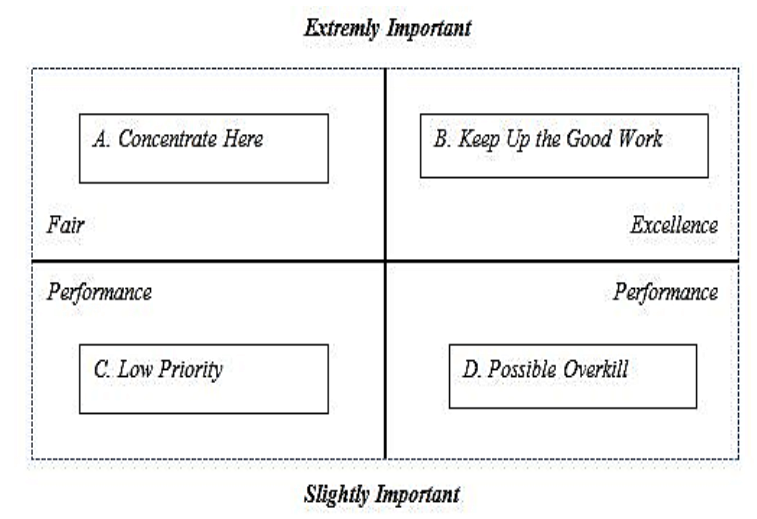

Gambar 1 Diagram Kartesius
Penjelasan mengenai keempat kuadran tersebut menurur Algifari (2016), yaitu:

\section{Kuadran A (Concentrate Here)}

Kuadran A menggambarkan bahwa pelanggan menganggap atribut tersebut penting, sehingga pelanggan memiliki harapan yang tinggi pada atribut tersebut, namun perusahaan tidak memberikan pelayanan terbaik pada atribut ini. Kuadran A mengisyaratkan perusahaan harus berkonsentrasi untuk memperbaiki segala kinerjanya pada atribut ini.

2. Kuadran B (Keep Up The Good Work)

Kuadran B menggambarkan atribut yang dianggap penting bagi pelanggan sementara perusahaan sudah memberikan pelayanan yang baik kepada pelanggan untuk atribut ini. Dengan demikian, pelayanan yang diberikan pada atribut di Kuadran B ini perlu dipertahankan.

3. Kuadran C (Low Priority)

Kuadran C pada model IPA menggambarkan atribut di Kuadran $B$ yang dianggap tidak penting oleh pelanggan sehingga dalam atribut Kuadran ini perusahaan perlu memberikan pelayanan dengan prioritas rendah.

\section{Kuadran D (Possible Overkill)}

Kuadran D menggambarkan wilayah dimana atribut memiliki kepentingan rendah bagi pelanggan, akan tetapi perusahaan memberikan pelayanan yang baik kepada pelanggan. Oleh karena itu, maka daerah ini disebut daerah berlebih.

\section{Hubungan Service Quality dengan Kepuasan Pelanggan}

Kualitas layanan yang diberikan oleh suatu perusahaan akan mempengaruhi kepuasan pelanggan yang menerima 
layanan tersebut. Berdasarkan penelitian Naik et al. (2010: 231) "service quality within retail units is pivotal for satisfying customers, retaining them and creating loyalty amongst customers." Hasil penelitian tersebut pun mengungkapkan bahwa service quality memiliki implikasi positif terhadap kepuasan pelanggan. Selain itu, berdasarkan penelitian Parasuraman et al. (1988) pun menunjukkan bahwa terdapat hubungan yang erat antara service quality dan kepuasan pelanggan.

Berdasarkan penjelasan tersebut, maka hipotesis pada penelitian ini adalah:

Ho: Service quality tidak berpengaruh secara positif dan signifikan terhadap kepuasan pelanggan Tol Purbaleunyi

Ha: $\quad$ Service quality berpengaruh secara positif dan signifikan terhadap kepuasan pelanggan Tol Purbaleunyi

\section{METODE PENELITIAN}

Populasi dan Sampel

Populasi dalam penelitian ini ialah seluruh pelanggan tol PT Jasa Marga (Persero) Cab. Purbaleunyi Populasi ini merupakan populasi tak terbatas karena tidak diketahui secara pasti ukuran populasi sebenarnya dari pelanggan tol Cab. Purbaleunyi.

Teknik sampling yang digunakan dalam penelitian ini adalah non probility sampling dengan cara pengambilan sampel menggunakan purposive sampling. Kriteria sampel dalam penelitian ini yakni setiap individu yang pernah menggunakan tol Purbaleunyi (Padalarang-Cileunyi ataupun Cipularang) maksimal dalam jangka waktu 2 bulan terakhir atau awal tahun 2017.

Jumlah sampel penelitian ini menggunakan 100 responden. Hal tersebut merujuk pada teori Fraenkel \& Wallen (dalam Hermawan \& Amirulloh, 2016: 135) yang menyatakan bahwa besar sampel minimum untuk penelitian deskriptif yaitu sebanyak 100 responden. Selain itu untuk menghindari kurangnya jumlah sampel yang dapat dianalisis datanya, peneliti menambah jumlah sampel. Wanrich dan Lininger dalam Dantes (2012) menyarankan menambah jumlah sampel sehingga jumlah sampel dalam penelitian ini yaitu 117 orang pelanggan Tol Purbaleunyi.

\section{Identifikasi Variabel dan Pengukuran}

Variabel independen, yaitu Service Quality (X) diukur menggunakan skala likert skala satu sampai lima. Angka satu mewakili sangat tidak setuju sedangkan angka lima mewakili sangat setuju. Instrumen pada variabel ini terdiri dari:

\section{Reliability (RE)}

$(\mathrm{RE} 1)=$ No traffic congestion

$(\mathrm{RE} 2)=$ Riding safety

$(\mathrm{RE} 3)=$ Smoothness of road surface

$(\mathrm{RE} 4)=$ Accuracy of information given

$($ RE5 $)=$ Security from crime

\section{Assurance (AS)}

$(\mathrm{AS} 1)=$ Toll gates operator services

$($ AS2 $)=$ Friendly toll gates operator

$(\mathrm{AS} 3)=$ Honest toll gates operator

\section{$\square$ Tangible (T)}

$(\mathrm{TA} 1)=$ Toll gates facilities

$(\mathrm{TA} 2)=$ Lighting

$(\mathrm{TA} 3)=$ Traffic sign and information board

(TA4) $=$ Facilities of rest area

\section{Emphaty (E)}

$(\mathrm{E} 1)=$ Call center service

$(\mathrm{E} 2)=$ Fast response of emergency unit

$\square$ Responsiveness (RES)

$($ RES1 $)=$ Accident handling

$($ RES2 $)=$ Responsiveness in road preservation

Variabel dependen, yaitu kepuasan pelanggan (Y) secara keseluruhan diukur menggunakan 4 butir pernyataan dengan jawaban berkisar dari sangat tidak puas hingga sangat puas. 


\section{Metode Analisis Data}

Penelitian ini menggunakan analisis deskriptif untuk menganalisa data dengan cara menggambarkan data yang telah terkumpul sebagaimana adanya tanpa maksud membuat kesimpulan yang berlaku untuk umum dan generalisasi (Sugiyono: 2013). Kemudian analisis kuadran digunakan untuk menggolongkan dan menyusun faktor determinan ke dalam importance performace matrix dengan dua sumbu, yakni sumbu $X$ mewakili persepsi atau performances, sedangkan sumbu $\mathrm{Y}$ mewakili harapan atau importance.

Analisis korelasi, regresi linear sederhana, dan uji hipotesis menggunakan uji $t$ dan uji $F$ digunakan untuk menggambarkan hubungan antara variabel $\mathrm{X}$ dan variabel $\mathrm{Y}$. Sementara analisis koefisien determinasi digunakan untuk mengukur seberapa jauh kemampuan model dalam menerangkan variasi variabel dependen (Ghozali: 2011).

Tabel 1 Identitas Responden

\begin{tabular}{|c|c|c|}
\hline & Frekuensi & Persentase \\
\hline \multicolumn{3}{|l|}{ Jenis Kelamin } \\
\hline Perempuan & 42 & $36 \%$ \\
\hline Laki-Laki & 75 & $64 \%$ \\
\hline \multicolumn{3}{|c|}{ Jenis Golongan Kendaraan } \\
\hline Golongan I & 99 & $84 \%$ \\
\hline Golongan II & 13 & $11 \%$ \\
\hline Golongan III & 3 & $3 \%$ \\
\hline Golongan IV & 2 & $2 \%$ \\
\hline \multicolumn{3}{|c|}{$\begin{array}{l}\text { Frekuensi penggunaan tol Purbaleunyi } \\
\text { dalam } 1 \text { bulan }\end{array}$} \\
\hline 1-2 kali & 62 & $53 \%$ \\
\hline 3-5 kali & 34 & $29 \%$ \\
\hline$>5$ kali & 23 & $18 \%$ \\
\hline
\end{tabular}

Sumber: Hasil olah data (2017)

\section{HASIL DAN PEMBAHASAN}

Mayoritas responden penelitian ini adalah laki-laki (64\%). Dilihat dari jenis golongan kendaraan responden, kendaraan golongan I mendominasi penelitian ini (84\%) sedangkan sisanya yakni kendaraan golongan II (11\%), kendaraan golongan III
$(3 \%)$, dan kendaraan golongan IV (2\%).

Sedangkan dilihat dari frekuensi penggunaannya, rata-rata responden menggunakan layanan tol Purbaleunyi sebanyak 1-2 kali dalam satu bulan (53\%), 3-5 kali dalam satu bulan (29\%) dan >5 kali dalam satu bulan (18\%).

Tabel 2 Deskriptif Service Quality

\begin{tabular}{|l|c|c|c|c|}
\hline \multicolumn{1}{|c|}{ Nama } & \multicolumn{2}{c|}{ Ekspektasi } & \multicolumn{2}{c|}{ Persepsi } \\
\hline Dimensi/Variabel & Mean & $\begin{array}{c}\text { Std. } \\
\text { Dev }\end{array}$ & Mean & $\begin{array}{c}\text { Std. } \\
\text { Dev }\end{array}$ \\
\hline $\begin{array}{l}\text { Dimensi } \\
\text { Reliability }\end{array}$ & 4.45 & .521 & 3.21 & .739 \\
\hline $\begin{array}{l}\text { Dimensi } \\
\text { Assurance }\end{array}$ & 4.54 & .562 & 3.63 & .651 \\
\hline Dimensi Tangible & 4.36 & .530 & 3.59 & .618 \\
\hline Dimensi Emphaty & 4.54 & .591 & 3.51 & .743 \\
\hline $\begin{array}{l}\text { Dimensi } \\
\text { Responsiveness }\end{array}$ & 4.52 & .587 & 3.41 & .812 \\
\hline Service Quality & $\mathbf{4 . 4 5}$ & $\mathbf{. 5 5 0}$ & $\mathbf{3 . 4 5}$ & $\mathbf{. 6 1 5}$ \\
\hline
\end{tabular}

Sumber: Hasil olah data (2017)

\section{Analisa Deskriptif}

Berdasarkan Tabel 2 dapat diketahui bahwa nilai mean ekspektasi pelanggan terhadap variabel service quality menunjukkan angka 4,45. Sedangkan nilai mean persepsi pelanggan yang menunjukkan kinerja aktual variabel service quality adalah sebesar 3,45. Nilai 3,45 tersebut berada pada interval 3,40-4,19 sehingga persepsi pelanggan terhadap variabel service quality dapat dikategorikan baik. Namun berdasarkan lima dimensi pada service quality, dimensi tangible merupakan dimensi dengan ekspektasi terendah, sedangkan assurance dan emphaty merupakan dimensi dengan nilai ekspektasi tertinggi.

Tabel 3 Deskriptif Kepuasan Pelanggan

\begin{tabular}{|l|c|c|}
\hline \multicolumn{1}{|c|}{ Item Pernyataan } & Mean & $\begin{array}{c}\text { Std. } \\
\text { Deviation }\end{array}$ \\
\hline Customer Satisfaction 1 & 3.71 & .788 \\
\hline Customer Satisfaction 2 & 3.66 & .697 \\
\hline Customer Satisfaction 3 & 3.56 & .712 \\
\hline Customer Satisfaction 4 & 3.45 & .804 \\
\hline Kepuasan Pelanggan & $\mathbf{3 . 6 0}$ & $\mathbf{. 6 1 1}$ \\
\hline
\end{tabular}

Sumber: Hasil olah data (2017) 
Berdasarkan Tabel 3 dapat diketahui bahwa nilai mean untuk variabel kepuasan pelanggan adalah sebesar 3,60. Nilai tersebut termasuk kedalam rentang 3,40-4,19 sehingga dikategorikan baik. Ini berarti secara kumulatif, pelanggan menilai layanan tol Jasa Marga Cab. Purbaleunyi sudah sukup memuaskan. Mean tertinggi berada pada pernyataan "jika saya memerlukan layanan jalan tol, saya yakin akan merasa puas dengan layanan tol Purbaleunyi."

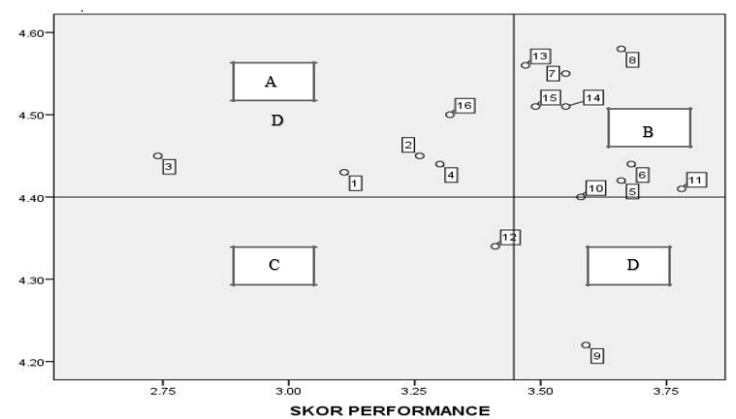

Sumber: Hasil olah data (2017)

Gambar 2 Important Performance Analysis

Pada kuadran A terdapat indikator no traffic congestion, riding safety, smoothness of road surface, accuracy of information given (dimensi reliability) dan responsiveness in road preservation. (dimensi responsiveness). Artinya dimensi service quality berupa reliability dan responsiveness dianggap penting oleh pelanggan, tetapi PT Jasa Marga (Persero) Cab. Purbaleunyi memberikan pelayanan dengan kualitas yang buruk. Oleh karena itu, manajemen PT Jasa Marga (Persero) Cab. Purbaleunyi perlu meningkatkan pelayanan kepada para pelanggan dari indikator-indikator ini.
Pada kuadran B terdapat indikator service quality berupa security from crime, toll gates operator services, friendly toll gates operator, honest toll gates operator, lighting, traffic sign and information board, call center service, fast response of emergency unit dan accident handling. Indikator-indikator ini telah diberikan PT Jasa Marga (Persero) Cab. Purbaleunyi dengan kualitas yang baik dan dinilai penting oleh pelanggan, sehingga manajemen PT Jasa Marga (Persero) Cab. Purbaleunyi perlu mempertahankan kualitas layanan yang diberikan kepada pelanggan untuk indikator-indikator ini.

Pada kuadran $\mathrm{C}$ terdapat indikator facilities of rest area, artinya, pelanggan menilai indikator ini kurang penting, disamping pelayanan untuk indikator ini dinilai dengan kualitas rendah. Oleh karena itu, manajemen tidak perlu terlalu memperhatikan indikator kualitas layanan ini. Atau dengan kata lain, atribut ini bukan merupakan prioritas, melainkan perlu dijadikan pendukung dalam layanan yang diberikan oleh jalan tol Purbaleunyi.

Pada kuadran D terdapat indikator toll gates facilities, artinya pelanggan menilai service quality kurang penting, walaupun PT Jasa Marga (Persero) Cab. Purbaleunyi telah memberikan pelayanan dengan kualitas tinggi. Oleh karena itu, manajemen PT Jasa Marga (Persero) Cab. Purbaleunyi perlu mengurangi usaha atau prioritas dalam memberikan pelayanan yang baik untuk indikator ini dan mengalihkan usaha perbaikan pelayanan pada indikator di kuadran A.

Tabel 3 Analisa Gap

\begin{tabular}{|c|c|c|c|c|}
\hline \multirow{2}{*}{ Dimensi } & Kode Item & $\begin{array}{c}\text { Average of } \\
\text { Expectation Score }(\text { E) }\end{array}$ & $\begin{array}{c}\text { Average of } \\
\text { Perception Score }(\boldsymbol{P})\end{array}$ & Gap Score $(\boldsymbol{P}-\boldsymbol{E})$ \\
\hline \multirow{4}{*}{ Reliability } & $\mathrm{RE} 1$ & 4,43 & 3,11 & $-1,32$ \\
\cline { 2 - 5 } & $\mathrm{RE} 2$ & 4,45 & 3,26 & $-1,19$ \\
\cline { 2 - 5 } & $\mathrm{RE} 3$ & 4,45 & 2,74 & $-1,71$ \\
\cline { 2 - 5 } & $\mathrm{RE} 4$ & 4,44 & 3,30 & $-1,14$ \\
\cline { 2 - 5 } & $\mathrm{RE} 5$ & 4.42 & 3,66 & $-0,76$ \\
\hline Rata-rata & & $\mathbf{4 , 4 5}$ & $\mathbf{3 , 2 1}$ & $\mathbf{- 1 . 2 2}$ \\
\hline
\end{tabular}




\begin{tabular}{|c|c|c|c|c|}
\hline \multirow{3}{*}{ sssurance } & AS1 & 4,44 & 3,68 & $-0,76$ \\
\cline { 2 - 5 } & AS2 & 4,55 & 3,55 & -1 \\
\cline { 2 - 5 } & AS3 & 4,58 & 3,66 & $-0,92$ \\
\hline \multirow{3}{*}{ Rata-rata } & & $\mathbf{4 . 5 4}$ & $\mathbf{3 . 6 3}$ & $\mathbf{- 0 , 8 9}$ \\
\hline \multirow{3}{*}{ Rata-rata } & TA1 & 4,22 & 3,59 & $-0,63$ \\
\cline { 2 - 5 } & TA2 & 4,40 & 3,58 & $-0,82$ \\
\cline { 2 - 5 } & TA3 & 4,41 & 3,78 & $-0,63$ \\
\hline \multirow{2}{*}{ Emphaty } & TA4 & 4,34 & 3,41 & $-0,93$ \\
\hline \multirow{2}{*}{ Rata-rata } & E1 & $\mathbf{4 , 3 6}$ & $\mathbf{3 , 5 9}$ & $-\mathbf{0 , 7 5}$ \\
\hline \multirow{2}{*}{ Eesponsiveness } & & 4,56 & 3,47 & $-0,09$ \\
\hline Rata-rata & RES1 & 4,51 & 3,55 & $\mathbf{- 1 , 0 2}$ \\
\hline RES2 & $\mathbf{4 , 5 4}$ & $\mathbf{3 , 5 1}$ & $-1,02$ \\
\hline Rata-rata & 4,51 & 3,49 & $-1,18$ \\
\hline
\end{tabular}

Sumber: Hasil olah data (2017)

Tabel 5 Analisis Korelasi

\begin{tabular}{|c|l|c|c|}
\hline & & Service Quality & Kepuasan Pelanggan \\
\hline \multirow{3}{*}{ Service Quality } & Pearson Correlation & 1 & $.527^{* *}$ \\
\cline { 2 - 4 } & Sig. (2-tailed) & & .000 \\
\cline { 2 - 4 } & $N$ & 117 & 117 \\
\hline \multirow{3}{*}{ Kepuasan Pelanggan } & Pearson Correlation & $.527^{* * *}$ & 1 \\
\cline { 2 - 4 } & Sig. (2- tailed) & .000 & 117 \\
\cline { 2 - 4 } & $N$ & 117 & 17 \\
\hline
\end{tabular}

**. Correlation is significant at the 0.01 level (2-tailed).

Sumber: Hasil olah data (2017)

\section{Analisis Korelasi}

Pada Tabel 5 dapat dilihat nilai korelasi antara variabel service quality dan kepuasan pelanggan sebesar 0,527. Mengacu Bungin (2010: 184), nilai korelasi sebesar 0,527 termasuk ke dalam interval $+0,50 \mathrm{ke}$ atas yang artinya terdapat nilai hubungan positif yang kuat (substantial). Nilai korelasi pearson pada Tabel 2 di atas menunjukkan nilai positif, yang artinya jika service quality meningkat maka akan diikuti oleh peningkatan kepuasan pelanggan pula. Dengan nilai signifikansi sebesar 0,000, maka korelasi tersebut signifikan karena nilai sig. $<0,05$ (Sugiama, 2008: 229).

\section{Analisis Regresi Sederhana}

Berdasarkan analisis regresi, diperoleh bahwa nilai konstanta (a) sebesar
7,170 dan nilai koefisien regresi (b) sebesar 0,131 . Maka dari itu, diperoleh persamaan regresi $\mathrm{Y}=7,170+0,131 \mathrm{X}$.

Tabel 6 Uji F

\begin{tabular}{|c|c|c|c|c|}
\hline Model & $\begin{array}{c}\text { Sum of } \\
\text { Squares }\end{array}$ & Df & $\begin{array}{c}\text { Mean } \\
\text { Square }\end{array}$ & $\boldsymbol{F}$ \\
\hline Regression & 187.49 & 1 & 187.49 & $\mathbf{4 2 . 5 9 6}$ \\
\hline${ }^{1}$ Residual & 506.19 & 115 & 4.40 & \\
\hline Total & 693.69 & 116 & & \\
\hline
\end{tabular}

Sumber: Hasil olah data (2017)

\section{Uji Hipotes}

Berdasarkan Tabel 6, dapat dilihat bahwa angka significant pada kolom Sig. adalah 0,000. Nilai tersebut lebih kecil dibandingkan dengan nilai probabilitasnya yang nilainya sebesar $0,05(5 \%)$. Apabila dilihat dari nilai $\mathrm{F}$ hitung $\left(\mathrm{F}_{0}\right)$ yang terlihat pada kolom $\mathrm{F}$ yang besarnya 42,596

Jurnal Riset Bisnis \& Investasi

Vol. 3, No. 2, Agustus 2017

ISSN 2460-8211 
dengan menggunakan tingkat signifikansi 0,05 serta df $_{1}:(\mathrm{k}-1)=2-1=1$ dan $\mathrm{df}_{2}:(\mathrm{n}$ $\mathrm{k})=117-2=115$, maka diperoleh $\mathrm{F}$ tabel $\left(F_{1}\right)$ sebesar 3,92 yang berarti bahwa nilai $F_{0} \geq F_{1}$ yaitu $42,596 \geq 3,92$. Mengacu pada interpretasi hasil uji statistik $\mathrm{F}$ menurut Arikunto (2010: 268), jika kriteria $F_{0} \geq F_{1}$ dengan taraf signifikansi 5\% maka interpretasinya adalah $\mathrm{H}_{0}$ ditolak dan $\mathrm{H}_{\mathrm{a}}$ diterima. Hal tersebut menunjukkan bahwa service quality berpengaruh secara positif dan signifikan terhadap kepuasan pelanggan.

Berdasarkan analisis regresi linier sederhana diperoleh nilai $\mathrm{t}$ hitung sebesar 6,527 . Dengan rumus df $=$ jumlah data -1 atau sebesar $117-1=116$, maka diperoleh t tabel 1,9806. Berdasarkan data tersebut, diperoleh nilai $t$ hitung yang lebih besar dari $\mathrm{t}$ tabel $(6,527>1,9806)$. Angka signifikansi pada kolom Sig. adalah 0,000, lebih kecil dibandingkan dengan nilai probabilitasnya sebesar 0,05 atau $5 \%$. Maka dari itu mengacu pada pendapat Priyatno (2013: 114) yang menyatakan bahwa jika kriteria $t$ hitung $>\mathrm{t}$ tabel dan tingkat signifikansi $<0,05$, maka interpretasinya adalah $\mathrm{H}_{\mathrm{o}}$ ditolak dan $\mathrm{H}_{\mathrm{a}}$ diterima. Hal tersebut menunjukan service quality berpengaruh secara positif dan signifikan terhadap kepuasan pelanggan.

Tabel 8 Analisis Koefisien Determinasi

\begin{tabular}{|l|c|c|c|c|c|}
\hline Model & $\boldsymbol{R}$ & $\begin{array}{c}\boldsymbol{R} \\
\text { Square }\end{array}$ & $\begin{array}{l}\text { Adjusted } \\
\boldsymbol{R} \text { Square }\end{array}$ & $\begin{array}{c}\text { Std. } \\
\text { Error of } \\
\text { the } \\
\text { Estimate }\end{array}$ & $\begin{array}{l}\text { Durbin- } \\
\text { Watson }\end{array}$ \\
\hline 1 & $.527^{\mathrm{a}}$ & .278 & .271 & 2.098 & 1.675 \\
\hline
\end{tabular}

Sumber: Hasil olah data (2017)

\section{Analisis Koefisien Determinasi}

Berdasarkan Tabel 8, nilai dari koefisien determinasi (R Square/R ${ }^{2}$ ) adalah 0,278 . Hal itu berarti bahwa $27,8 \%$ perubahan kepuasan pelanggan dapat dijelaskan oleh variabel service quality, sedangkan sisanya sebesar $73,2 \%$ dijelaskan oleh kontribusi faktor lain. Hal ini berarti bahwa hubungan kedua variabel antara service quality dengan kepuasan pelanggan cukup kuat.

\section{KESIMPULAN DAN SARAN Kesimpulan}

1. Persepsi service quality yang dirasakan pelanggan tol Purbaleunyi secara keseluruhan dikategorikan sudah baik. Dari kelima dimensi service quality yaitu reliability, assurance, tangible, emphaty dan responsiveness berada pada kategori yang baik pula.

2. Secara kumulatif, kepuasan pelanggan tol Purbaleunyi berada pada kategori baik. Mean tertinggi berada pada pernyataan "jika saya memerlukan layanan jalan tol, saya yakin akan merasa puas dengan layanan tol Purbaleunyi."

3. Terdapat pengaruh yang positif dan signifikan dari service quality terhadap kepuasan pelanggan pada tol Purbaleunyi.

\section{Saran}

Berdasarkan important performance analysis yang telah dibuat sebelumnya, berikut merupakan prioritas perbaikan yang dapat dilakukan oleh PT Jasa Marga (Persero) Cab. Purbaleunyi:

1. Memfokuskan prioritas perbaikan utama pada indikator no traffic congestion, riding safety, smoothness of road surface, accuracy of information given dan responsiveness in road preservation. Perbaikan pada indikator no traffic congestion dapat dilakukan dengan cara memaksimalkan operasional gardu tol yang ada, yakni membuka semua gardu yang tersedia, dan penambahan jumlah gardu tol otomatis saat terjadi kemacetan. Perbaikan pada indikator riding safety dapat dilakukan dengan cara memberikan pelatihan kepada petugas lapangan mengenai aturan-aturan dasar penempatan marka jalan yang baik dan 
benar agar tidak membahayakan pelanggan. Perbaikan pada indikator smoothness of road dapat dilakukan dengan meningkatkan frekuensi perawatan dan pemeliharaan jalan tol (preventive maintenance) contohnya dengan melakukan surface dressing pada permukaan jalan tol yang aspalnya cenderung mengalami penuaan/ageing. Perbaikan untuk indikator accuracy of information given dapat dilakukan dengan melakukan sidak dan sistem sanksi terhadap oknum-oknum petugas yang memberikan informasi yang tidak sesuai dengan yang seharusnya. Sehingga keakuratan informasi menjadi tetap terjaga saat dilapangan. Sedangkan perbaikan untuk indikator responsiveness in road preservation dapat dilakukan dengan dilaksanakannya pengendalian pelaksanaan di lapangan. Hal tersebut dikarenakan tinggi rendahnya mutu produk pekerjaan pemeliharaan tergantung kepada segitiga fungsional yang terdiri atas pihak Proyek Pemeliharaan dan Peningkatan Jalan Tol (P2JT) / Satgas Cabang, Konsultan Supervisi, dan Pelaksana/Kontraktor.

2. Mempertahankan kualitas pelayanan pada indikator-indikator di kuadran B yakni security from crime, toll gates operator services, friendly toll gates operator, honest toll gates operator, lighting, traffic sign and information board, call center service, fast response of emergency unit dan accident handling. Indikator-indikator ini dianggap tinggi tingkat kepetingannya dan dinilai telah tinggi pula kinerjanya oleh para pelanggan.

3. Mengesampingkan perbaikan kualitas pada indikator di kuadran $\mathrm{C}$ yakni facilities of rest area. Hal ini dikarenakan indikator ini dinilai tingkat kepentingannya cukup rendah, dan PT Jasa Marga (Persero) Cab. Purbaleunyi pun telah memberikan kualitas yang rendah pula pada indikator ini. Jadi, atribut ini bukan merupakan prioritas, melainkan hanya perlu dijadikan pendukung dalam layanan yang diberikan oleh jalan tol Purbaleunyi.

4. Mengurangi usaha perbaikan indikator yang berada pada kuadran D yakni toll gates facilities dan mengalihkan usaha perbaikan pelayanan pada indikator di kuadran A, karena indikator ini dinilai terlalu tinggi oleh pelanggan, sedangkan tingkat kepentingannya tidak terlalu demikian dimata pelanggan.

\section{DAFTAR PUSTAKA}

Algifari. (2016). Mengukur Kualitas Layanan dengan Indeks Kepuasan, Metode Importance Performance Analysis (IPA) dan Model Kano. Yogyakarta: BPFE-Yogyakarta

Arikunto, S. (2010). Prosedur penelitian : Suatu Pendekatan Praktik. (Edisi Revisi). Jakarta : Rineka Cipta

Bitner, M. J., \& Hubbert, A. R. (1994). Encounter satisfaction versus overall satisfaction versus quality. Service quality: New directions in theory and practice, 34, 72-94.

Bungin, B. (2010). Penelitian Kualitatif : Komunikasi, Ekonomi, Kebijakan Publik dan Ilmu Sosia lainnya. Jakarta: Kencana Prenama Media Group

Dantes, N. (2012). Metode Penelitian. Yogyakarta: Andi Offset

Daryanto \& Setyobudi, I. (2014). Pelanggan dan Pelayanan Prima. Yogyakarta: Gava media

Greenberg, P. (2010). Customer Relationship Management as the Speed of Light: Fourth Edition. McGraw-Hill.

Ghozali, I. (2011). Aplikasi Analisis Multivariate dengan Program SPSS. Semarang: Badan Penerbit Universitas 
Diponegoro, Hermawan, S. \& Amirullah. (2016). Metode Penelitian Bisnis (Pendekatan dan Kualitatif). Malang: Media Nusa Creative

Hindarwati, E. N., \& Jayasari, A. (2014). Analisis Kualitas Pelayanan PT Jasa Raharja dengan Metode Servqual. Binus Business Review, 5(2), 626637.

Lupiyoadi, R. (2013). Manajemen Pemasaran Jasa. Jakarta: Salemba Empat

Naik, C. N. K., Gantasala, S. B. \& Prabhakar, G. V. (2010). Service Quality (Servqual) and its Effect on Customer Satisfaction. European Journal of Social Sciences Colume 16 , Number 2

Osotimehin, K., Hassan, B. A., \& Abass, H. (2015). Customers Perception of Service Quality in the Nigerian Telecommunication Sector. Journal of Economics and Business Research, 21(1), 144-157.

Parasuraman, A., Zeithaml V. A., Berry, L. L. (1988), "SERVQUAL: A MultipleItem Scale for Measuring Consumer
Perceptions of Service Quality," Journal of Retailing, 64 (Spring).

Phan, C., \& Nham, P. (2015). Impact of service quality on customer satisfaction of automated teller machine service: case study of a private commercial joint stock bank in Vietnam. Business: Theory and Practice, 16, 280.

Priyatno, D. (2013). Mandiri Belajar Data dengan SPSS. Yogyakarta: Mediakom

Sugiama. A. G. (2008). Metode Riset Bisnis dan Manajemen. Bandung: Guardaya Intimarta

Taylor, S. A., \& Baker, T. L. (1994). An assessment of the relationship between service quality and customer satisfaction in the formation of consumers' purchase intentions. Journal of retailing, 70(2), 163-178. Tjiptono, Fandy \& Chandra, Gregorius. 